\title{
Histopatologi Ginjal Ikan Jambal Siam (Pangasiodon hypophthalmus) yang Diberi Pakan Mengandung Tepung Kunyit
}

\author{
Histopathology of Kidney of Striped Catfish \\ (Pangasiodon hypophthalmus) Feed with Turmeric Flour
}

\author{
Sri Wahyuni ${ }^{1 *}$, Morina Riauwaty ${ }^{2}$, Windarti $^{2}$ \\ 'Mahasiswa Pascasarjana Ilmu Kelautan, Universitas Riau \\ ${ }^{2}$ Dosen Fakultas Perikanan dan Kelautan, Universitas Riau \\ *Email: srayuni17@gmail.com
}

\begin{abstract}
Abstrak
Diterima

17 september 2020

Kunyit merupakan salah satu tanaman herbal yang memiliki sifat antibakteri dan antioksidan, serta mampu meningkatkan sistem imun ikan. Tujuan dari penelitian ini adalah untuk melihat struktur jaringan ginjal dan kelulushidupan ikan yang diberi pakan mengandung tepung kunyit sebelum dan setelah diuji tantang bakteri Aeromonas hydrophila. Penelitian ini dilaksanakan pada bulan Februari sampai

Disetujui Mei 2019 di Laboratorium Parasit dan Penyakit Ikan Fakultas Perikanan dan

10 Oktober 2020 Kelautan Universitas Riau. Metode yang digunakan dalam penelitian ini adalah metode eksperimen dengan menerapkan Rancangan Acak Lengkap (RAL) satu faktor dengan lima taraf, yaitu Kn (pemberian pakan tanpa diberi tepung kunyit dan tanpa diinfeksi bakteri A. hydrophila), Kp (Pemberian pakan tanpa diberi tepung kunyit dan diinfeksi bakteri A. hydrophila), P1 (tepung kunyit dengan dosis 0,5 g/kg pakan), P2 (dosis 0,7 g/kg pakan), P3 (dosis 0,9 g/kg pakan). Hasil penelitian menunjukkan bahwa struktur jaringan ikan jambal siam yang diberi penambahan tepung kunyit dalam pakan dalam keadaan normal dan setelah diuji tantang dengan bakteri A. hydrophila mengalami beberapa kerusakan pada jaringan ginjal. Dosis terbaik penambahan tepung kunyit pada pakan adalah 0,7 $\mathrm{g} / \mathrm{kg}$ pakan (P2). Struktur jaringan ginjal pada perlakuan P2 memiliki kerusakan seperti hemoragi dan kelulushidupan $100 \%$.
\end{abstract}

Kata kunci: struktur jaringan ginjal, tepung kunyit, kelulushidupan

\begin{abstract}
Turmeric is an herbal plant that has antibacterial and antioxidant abilities, and also to improve the fish's immune system. The aim of this research was to look at the histological structure of kidney and survival rate fish which was given feed with turmeric flour before and after infected with A. hydrophila. This research was conducted from February to May 2019 in the Laboratory of Parasites and Fish Diseases of the Faculty of Fisheries and Marine Sciences, University of Riau. The method in this research was the experimental method by one-factor Completely Randomized Design (CRD) with five levels. Kn (feeding without given turmeric flour and without infection with A. hydrophila), Kp (Feeding without given turmeric flour and infected with A. hydrophila), $\mathrm{P} 1$ (turmeric flour at a dose of 0.5 $\mathrm{g} / \mathrm{kg}$ of feed), P2 (dose of $0.7 \mathrm{~g} / \mathrm{kg}$ ), P3 (dose of $0.9 \mathrm{~g} / \mathrm{kg}$ ). The results showed that the histological structure of catfish which was given the addition of turmeric flour in feed by normal conditions and after being challenged with A. hydrophila showed some damage to the gill and kidney structure. The best dose of adding turmeric flour to feed is $0.7 \mathrm{~g} / \mathrm{kg}$ of feed (P2), seen from the structure of the kidney cell, and the best survival. Histological structure of kidney cell structure in
\end{abstract}


P2 treatment has abnormality such as hemorrhage and survival rate $100 \%$.

Keyword: kidney structure; turmeric flour, survival rate

\section{Pendahuluan}

Ikan jambal siam (Pangasiodon hypophthalmus) merupakan salah satu ikan air tawar yang bernilai ekonomis tinggi dan sangat digemari masyarakat karena rasanya yang enak dan dagingnya yang tebal. Kendala dalam usaha budidaya salah satunya adalah disebabkan adanya serangan penyakit. Pada dasarnya timbulnya serangan penyakit karena adanya gangguan keseimbangan antara ikan dengan lingkungan yang tidak saling menguntungkan sehingga menyebabkan perkembangan patogen lebih cepat yang menimbulkan penyakit di dalam perairan. Salah satu patogen penyebab penyakit yang sering menyerang ikan air tawar adalah bakteri.

Bakteri yang sering menyebabkan kematian ikan air tawar salah satunya adalah bakteri Aeromonas hydrophila. Infeksi $A$. hydrophila pada ikan jambal siam akan menunjukkan tanda seperti bercak-bercak merah pada kulit yang disebut Motile Aeromonas Septicemia (MAS) atau lebih sering dikenal sebagai penyakit bercak merah (Kurniawan, 2011). Salah satu upaya dalam pencegahan infeksi bakteri dengan menggunakan bahan alami. Penggunaan bahan alami terbukti efektif dan tidak memiliki dampak negatif pada manusia maupun lingkungan. Senyawa aktif kunyit sudah terbukti dapat mencegah infeksi bakteri A. hydrophila pada ikan patin (Karmila, 2017).

Riauwaty (2007) menyatakan bahwa pemberian kunyit secara rendaman dapat meningkatkan daya tahan tubuh ikan mas. Ikan mengalami pemulihan pasca perendaman dengan ekstrak kunyit selama satu jam. Akan tetapi, metode rendaman ini dapat menimbulkan stress pada ikan. Oleh karena itu perlu adanya alternatif lain dalam memberikan kunyit pada ikan. Salah satu cara pemberian kunyit yang tidak menimbulkan stress adalah dengan mencampurkan kunyit tersebut dengan pakan ikan yang diperkaya dengan tepung kunyit. Selain itu, ikan jambal siam yang diberi penambahan ekstrak kurkumin dari kunyit (Curcuma domestica V.) pada pakan menunjukkan tingkat kelulushidupan ikan jambal siam $100 \%$ (Iman, 2017), serta mampu memperbaiki kerusakan struktur jaringan hati dan usus ikan jambal siam yang terinfeksi bakteri A. hydrophila (Zulaiha et al., 2017).

Menurut Hariani dan Purnomo (2017) bahwa pemberian pakan yang mengandung kunyit memiliki senyawa aktif yang bertindak sebagai antioksidan dan memelihara kesehatan dengan meningkatkan daya tahan tubuh, dan memperbaiki nafsu makan pada benih ikan lele. Dengan meningkatnya daya tahan tubuh ikan maka serangan $A$. hydrophila dapat ditangkal. Informasi tentang penggunaan tepung kunyit pada pakan terhadap perubahan struktur organ insang dan ginjal pada ikan jambal siam yang diuji tantang bakteri A. hydrophila masih terbatas. Penelitian ini bertujuan untuk melihat struktur jaringan ginjal dan kelulushidupan ikan jambal siam yang diberi pakan mengandung tepung kunyit.

\section{Bahan dan Metode}

\subsection{Waktu dan Tempat}

Penelitian ini telah dilaksanakan pada bulan Februari sampai Mei 2019 di Laboratorium Parasit dan Penyakit Ikan Fakultas Perikanan dan Kelautan Universitas Riau.

\subsection{Metode Penelitian}

Metode yang digunakan dalam penelitian ini adalah metode eksperimen dengan menerapkan Rancangan Acak Lengkap (RAL) satu faktor dengan lima taraf. Untuk mengurangi tingkat kekeliruan maka dilakukan ulangan sebanyak tiga kali sehingga diperlukan 15 unit percobaan. Metode pembuatan preparat histologi dan metode pewarnaan Haematoxylin dan Eosin (HE) menurut Windarti dan Simarmata (2015). Perlakuan dalam penelitian ini mengacu Selvi et al. (2016) dengan lima taraf perlakuan, yaitu :

Kn :Kontrol negatif (Pemberian pakan tanpa diberi tepung kunyit dan tanpa diinfeksi bakteri A.hydrophila)

Kp :Kontrol positif (Pemberian pakan tanpa diberi tepung kunyit dan diinfeksi bakteri A.hydrophila)

P1 : Pakan yang mengandung kunyit dengan dosis $0,5 \mathrm{~g} / \mathrm{kg}$ pakan

P2 :Pakan yang mengandung kunyit dengan dosis $0,7 \mathrm{~g} / \mathrm{kg}$ pakan

P3 :Pakan yang mengandung kunyit dengan dosis $0,9 \mathrm{~g} / \mathrm{kg}$ pakan

\subsection{Prosedur Penelitian}

Pembuatan preparat struktur jaringan ginjal dilakukan menurut Windarti dan Simarmata (2015). Sampel akan difiksasi dengan formalin 10\% selama 24-48 jam dan dipindahkan ke formalin 4\%. Setelah itu dilakukan proses dehidrasi yaitu sampel yang telah difiksasi dipindahkan ke dalam alkohol seri bertingkat mulai dari $70 \%$, $80 \%, 90 \%, 96 \%$ dan alkohol absolut masing-masing selama 1 jam. Khusus untuk perendaman dalam alkohol 
absolut dilakukan 2 kali, masing-masing 1 jam. Selanjutnya sampel dimasukkan lagi ke dalam larutan xylol murni sebanyak dua kali dan masing-masing selama 1 jam. Setelah itu, sampel dimasukkan ke dalam larutan xylol : parafin (1:1) selama 1 jam (proses dilakukan dalam oven $60{ }^{\circ} \mathrm{C}$ ). Kemudian sampel direndam dalam parafin murni sebanyak dua kali dan masing-masing dilakukan selama 1 jam. Proses selanjutnya sampel ditanam dalam parafin dengan menggunakan cetakan (kertas tebal) dan dibiarkan mengeras dalam suhu kamar.

Kemudian sampel dipotong dengan mikrotom dengan ketebalan $5 \mu \mathrm{m}$. Pita parafin kemudian diletakkan diatas water bath. Selanjutnya pita paraffin diambil menggunakan objek glass dan dibiarkan sampai kering. Supaya sampel dapat melekat kuat pada objek glass diberi perekat yang terbuat dari glyserin dan albumin (1:1). Setelah itu sampel dikeringkan pada oven dryer yang diaturpada suhu $45^{\circ} \mathrm{C}$ selama minimal 24 jam. Kemudian sampel diwarnai dengan menggunakan Haematoxylin dan Eosin (HE).

Adapun prosedur pewarnaan adalah sebagai berikut: mula-mula parafin pada preparat harus dihilangkan dengan cara merendam sampel dengan xylol selama 2 menit. Kemudian dilakukan rehidrasi dengan mencelupkan preparat ke dalam alkohol seri turun, dari absolut sampai 35\% masing-masing selama 2 menit. Setelah itu,sampel direndam dalam larutan haematoxylin selama 4 menit, dicuci dengan air mengalir. Selanjutnya sampel direndam dalam larutan eosin selama 1,5 menit dan dicuci dengan menggunakan air mengalir.

Proses terakhir yaitu proses penutupan, proses ini dimulai dengan cara mencelupkan dalam alkohol seri naik mulai dari 70\%, 80\%, 90\%, 96\% dan absolut selama 20 detik. Selanjutnya preparat dimasukkan ke dalam larutan xylol murni selama 2 menit. Setelah itu sampel ditetesi dengan entellan neu dan ditutup dengan cover glass. Preparat yang sudah ditutup kemudian disimpan dalam oven dryer selama 2-3 hari. Preparat siap untuk diamati menggunakan mikroskop Olympus CX21.

\subsection{Analisis Data}

Data yang diperoleh dari kelulushidupan ikan dianalisis menggunakan analisis variansi (ANOVA) apabila perlakuan menunjukkan perbedaan yang nyata dimana $\mathrm{p}<0,05$ maka dilakukan uji lanjut Student Newman-Keuls untuk menentukan perbedaan dari masing-masing perlakuan. Data abnormalitas ginjal dianalisis dan dibahas secara deskriptif.

\section{Hasil dan Pembahasan}

\subsection{Struktur Jaringan Ginjal}

Struktur jaringan ginjal ikan jambal siam pada yang dipelihara selama 30 hari dan diberi pakan mengandung tepung kunyit tidak mengalami kerusakan. Struktur ginjal ikan jambal siam normal tersusun rapi oleh glomelurus yang diselubungi oleh kapsul bowman. Glomelurus dan kapsul bowman berbentuk seperti angka enam dengan ukuran yang sama. Pada keadaan normal glomerulus yang bentuknya masih nampak nyata, tidak berbentuk bulat utuh tapi menyerupai angka enam (Wahyuni et al., 2017). Hal ini menunjukkan bahwa struktur jaringan ginjal ikan jambal siam yang dipelihara selama 30 dan diberi pakan mengandung tepung kunyit masih dalam keadaan normal. Untuk lebih jelas dapat dilihat pada Gambar 1.

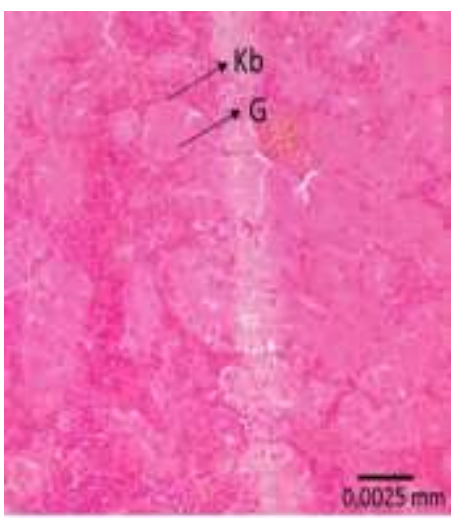

P1

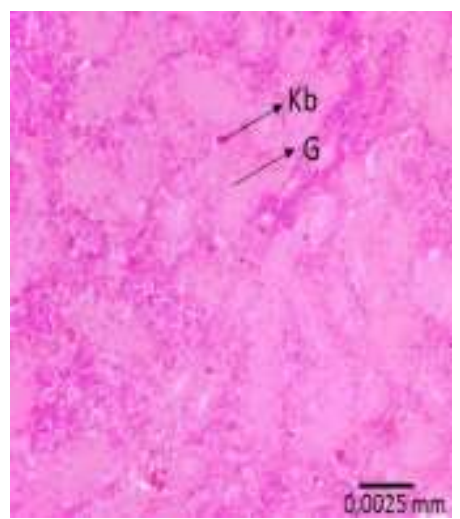

P2

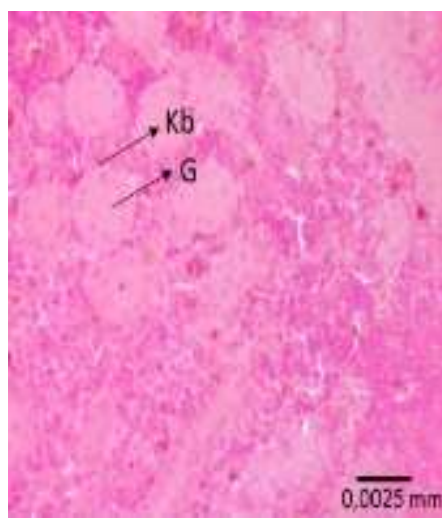

P3

Gambar 1. Struktur Jaringan Insang Ikan Jambal Siam yang diberi pakan mengandung tepung kunyit selama 30 hari pemeliharaan $[\mathrm{KB}=$ kabsul bowman, $\mathrm{G}=$ glomerulus $]$

Struktur jaringan ginjal ikan jambal siam pasca diuji tantang dengan bakteri A. hydrophila pada perlakuan Kn struktur ginjal ikan terdapat pigmentasi. Pigmentasi bukan merupakan suatu kelainan/ abnormalitas. Pigmentasi dapat terjadi dikarenakan beberapa faktor internal seperti umur, gen dan jenis kelamin. Sedangkan kerusakan jaringan ginjal pada perlakuan tanpa pemberian tepung kunyit (Kp) struktur ginjal ikan tidak normal, terdapat pendarahan hampir disemua bagian ginjal (hemoragi), sel-sel membesar (hypertrophy), dan nekrosis. 
Hypertrophy disebabkan ukuran sel membesar sehingga akan tampak seperti glomerulus membesar. Pada struktur jaringan ginjal terlihat bahwa sel darah berada ditempat yang tidak semestinya atau yang dikenal dengan pendarahan/hemoragi. Untuk lebih jelas dapat dilihat pada Gambar 2.

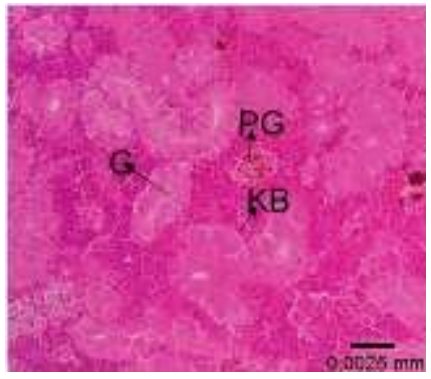

$\mathrm{Kn}$

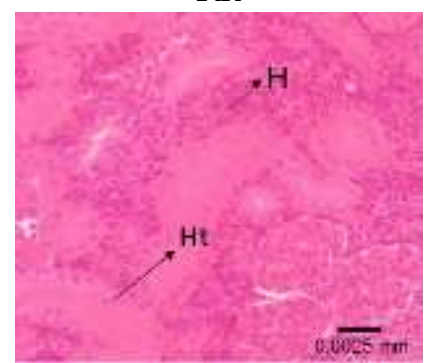

P1

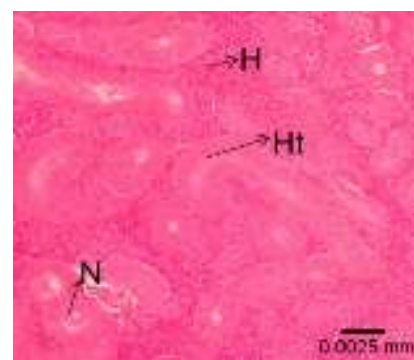

$\mathrm{Kp}$

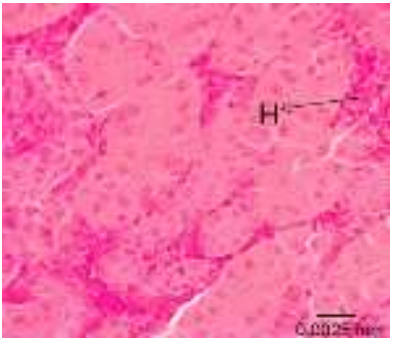

P2

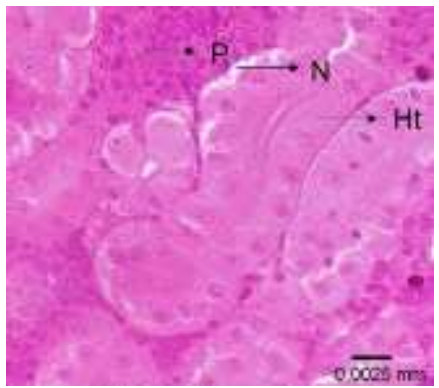

P3

Gambar 2. Struktur Jaringan Ginjal Ikan Jambal Siam Pasca Diuji Tantang dengan Bakteri A. hydrophila [Kn $=$ Kontrol negatif (pemberian pakan tanpa diberi tepung kunyit dan tidak diuji tantang dengan bakteri A. hydrophila), Kp = Kontrol positif (pemberian pakan tanpa diberi tepung kunyit dan diuji tantang dengan bakteri A. hydrophila), P1 = penambahan tepung kunyit pada pakan dengan dosis $0,5 \mathrm{~g} / \mathrm{kg}, \mathrm{P} 2=$ dosis $0,7 \mathrm{~g} / \mathrm{kg}, \mathrm{P} 3=$ dosis $0,9 \mathrm{~g} / \mathrm{kg}, \mathrm{G}=$ Glomerulus, $\mathrm{KB}=$ Kapsul Bowman, $\mathrm{PG}=$ Pigmentasi, $\mathrm{H}=$ Hemoragi, $\mathrm{Ht}=$ Hypertrophy, Nekrosis $]$

Kerusakan jaringan ginjal ikan jambal siam pada perlakuan Kp dikarenakan infeksi bakteri A. hydrophila. Pendarahan dalam jaringan ginjal diduga karena kadar leukosit, leukosit meningkat kemudian menuju daerah terinfeksi untuk memfagosit bakteri A. hydrophila. Menurut Utami et al. (2013) pada saat terjadi infeksi oleh benda asing, maka monosit akan bergerak cepat meninggalkan pembuluh darah menuju daerah yang terinfeksi untuk melakukan fagositosit.

Serangan bakteri A. hydrophila dimulai dari melekatnya bakteri pada permukaan kulit dengan memanfaatkan pili, flagel dan kait untuk bergerak dan melekat pada pada lapisan luar tubuh. Kemudian $A$. hydrophila memproduksi enzim kitinase untuk mendegradasi lapisan kitin, sehingga bakteri bisa masuk ke tubuh ikan. Selanjutnya $A$. hydrophila memproduksi enzim litinase dalam upaya masuk ke aliran darah dan dapat menghasilkan enzim hemolisin yang mampu melisis darah (Mastuti et al., 2017). Infeksi bakteri $A$. hydrophila masuk ke dalam darah dan dengan mudah mencapai organ - organ penting seperti ginjal. Ginjal akan dimanfaatkan oleh bakteri $A$. hydrophila sebagai tempat memperbanyak diri, serta mengambil nutrisi yang ada disekitarnya untuk proses metabolisme, hal ini mengakibatkan kerusakan jaringan pada ginjal ikan patin (Safratilofa, 2017).

Kerusakan struktur ginjal pada perlakuan Kp yang paling parah yaitu kematian sel / nekrosis. Kematian sel ditandai dengan hilangnya beberapa bagian sel yang akan nampak seperti lubang pada glomerulus. Nekrosis terjadi akibat reaksi peradangan yang menimbulkan kerusakan pada jaringan yang diikuti dengan kematian sel akibat adanya infeksi bakteri A. hydrophila (Cahyaningrum et al., 2015). Menurut Wikiandy et al. (2013), 
nekrosis secara histologi ditandai dengan terlihatnya batas-batas sel dan inti sel tidak jelas atau bahkan menghilang.

Struktur jaringan ginjal ikan jambal siam pasca diuji tantang pada perlakuan P1, P2 dan P3 tidak separah kerusakan pada Kp. Kerusakan pada perlakuan pemberian kunyit hampir sama, pada perlakuan P1 dan P3 terdapat pendarahan (hemoragi) dan sedikit hypertrophy sel glomerulus, dan pada $\mathrm{P} 2$ terdapat kerusakan berupa pendarahan. Hal ini dikarenakan tapung kunyit memiliki senyawa antimikroba seperti flavonoid. Menurut Septiana (2011) bahwa flavonoid juga membantu menghambat produksi enteretoksin sehingga organ yang memproduksi darah kembali normal. Dengan demikian hal ini menunjukkan bahwa dengan adanya pemberian tepung kunyit dapat mencegah kerusakan struktur jaringan ginjal ikan akibat serangan A. hydrophila.

\subsection{Kelulushidupan Ikan}

Tingkat kelulushidupan ikan selama 30 hari pemeliharaan mencapai 100\%. Kandungan vit C dalam tepung kunyit meningkatkan daya tahan tubuh ikan (Hariani dan Purnomo, 2017). Selain itu, wadah pemeliharaan dan lingkungan juga memadai untuk ikan jambal siam hidup. Kelulushidupan ikan jambal siam yang diberi pakan mengandung tepung kunyit dan pasca diuji tantang dengan bakteri A. hydrophila disajikan pada Tabel 1.

Tabel 1. Tingkat Kelulushidupan Ikan Jambal Siam Pasca Diuji Tantang

\begin{tabular}{cccc}
\hline \multirow{2}{*}{ Perlakuan } & \multicolumn{3}{c}{ Tingkat Kelulushidupan (\%) } \\
\cline { 2 - 4 } & 30 hari pemeliharaan & $\begin{array}{c}\text { Setelah 14 hari Diuji } \\
\text { tantang }\end{array}$ & SR \\
\hline $\mathrm{Kn}$ & 100 & 100 & $100,00 \pm 0,00^{\mathrm{a}}$ \\
$\mathrm{Kp}$ & 100 & 40 & $40,00 \pm 10,00^{\mathrm{c}}$ \\
$\mathrm{P}_{1}$ & 100 & 96 & $96,67 \pm 5.77^{\mathrm{a}}$ \\
$\mathrm{P}_{2}$ & 100 & 100 & $100,00 \pm 0,00^{\mathrm{a}}$ \\
$\mathrm{P}_{3}$ & 100 & 80 & $80,00 \pm 10,00^{\mathrm{b}}$ \\
\hline
\end{tabular}

Tabel 1 menunjukkan bahwa tingkat kematian ikan jambal siam pasca diuji tantang dengan bakteri $A$. hydrophila yang mencapai $60 \%$, disebabkan oleh ikan mengalami stress akibat adanya ulcer dan pendarahan karena infeksi bakteri. Selain itu, A. hydrophila menghasilkan toksin seperti hemolisin, sitotoksin, dan enterotoksin. Hemolisin dan enzim bekerja sama dalam membuka jaringan permukaan kulit dan sisik ikan (Mangunwardoyo et al., 2010). Infeksi bakteri A. hydrophila ini juga bersifat akut, menginfeksi semua umur dan jenis ikan air tawar, dan dapat mengakibatkan kematian ikan mencapai 100\% (Taukhid et al., 2016).

Kelulushidupan ikan jambal siam dengan pemberian pakan yang diperkaya tepung kunyit dan diuji tantang dengan A. hydrophila berkisar antara 80-100\% lebih tinggi dibandingkan dengan kontrol positif (KP), yaitu 40\%. Hal ini disebabkan karena adanya kandungan senyawa metabolit, seperti kurkumin, vitamin C dan flavonoid. Samsundari (2006) menyatakan bahwa zat kurkumin mempunyai khasiat antibakteri yang dapat merangsang dinding kantong empedu sehingga dapat memperlancar metabolisme lemak, anti peradangan, antioksidan, antibakteri, dan juga dapat digunakan untuk meningkatkan kekebalan tubuh. Selain itu, vitamin C berperan penting dalam menormalkan fungsi kekebalan tubuh dan mengurangi stress (Jusadi et al., 2006), serta membantu reaksi tubuh terhadap stress fisiologi, pencegahan penyakit dan penting untuk pertumbuhan (Komalasari et al., 2017). Senyawa aktif dalam tepung kunyit yaitu kurkumin dan minyak atsiri yang mampu meningkatkan sistem imun sehingga daya tahan tubuh ikan saat terinfeksi bakteri A. hydrophila dalam kondisi kuat dan dapat mempertahankan kelangsungan hidupnya (Yolanda, 2019).

Berdasarkan hasil ANOVA Kn, P1, dan P2 tidak berbeda nyata, P3 berbeda nyata dengan Kn, P1 dan P2, dan sangat berbeda nyata dengan Kp. Hal ini menunjukkan bahwa pemberian pakan yang mengandung tepung kunyit dan diuji tantang dengan Aeromonas hydrophila mampu meningkatkan kelulushidupan ikan jambal siam mencapai $100 \%$ pada perlakuan P2 dengan dosis tepung kunyit $0,7 \mathrm{~g} / \mathrm{kg}$ pakan.

\section{Kesimpulan}

Berdasarkan hasil penelitian dapat disimpulkan bahwa struktur jaringan ginjal ikan jambal siam yang diberi penambahan tepung kunyit dalam pakan dalam keadaan normal dan setelah diuji tantang dengan bakteri $A$. hydrophila mengalami beberapa kerusakan pada jaringan insang dan ginjal. Dosis terbaik penambahan tepung kunyit pada pakan adalah $0,7 \mathrm{~g} / \mathrm{kg}$ pakan $(\mathrm{P} 2)$, dilihat dari struktur jaringan ginjal terbaik. Struktur jaringan ginjal pada perlakuan P2 memiliki kerusakan seperti hemoragi dan SR 100\%.

\section{Referensi}

Bako, S., I. Lukistyowati dan M. Riauwaty. 2019. Sensitivitas Larutan Propolis terhadap Bakteri Aeromonas hydrophila. Jurnal Perikanan dan Kelautan, 24(2): 91-100 
Cahyaningrum, D., Sarjito, dan A.H.C. Haditomo. 2015. Pengaruh Perendaman Ekstrak Daun Ceremai (Phyllanthus Acidus [L] Skeels) Terhadap Kelulushidupan dan Histopatologi Ginjal Ikan Patin (Pangasius hypophthalmus) yang Diinfeksi Bakteri Aeromonas hydrophila. Journal of Aquaculture Management and Technology, 4(1), 40-46.

Jusadi, D., E. Gandara dan I. Mokoginta. 2004. Pengaruh Penambahan Probiotik Bacillus sp. pada Pakan Komersil terhadap Konversi pakan dan Pertumbuhan Ikan Patin (Pangasius hypophthalmus). Jurnal Akuakultur Indonesia 3(1) : 15-18.

Hariani, D., dan T. Purnomo. 2017. Pemberian Probiotik dalam Pakan untuk Budidaya Ikan Lele. STIGMA: Jurnal Matematika dan Ilmu Pengetahuan Alam Unipa, 10(1), 31-35.

Komalasari, S.S., Subandiyono, dan S. Hastuti. 2017. Pengaruh Vitamin C pada Pakan Komersil dan Kepadatan Ikan terhadap Kelulushidupan serta Pertumbuhan Ikan Nila (Oreochromis niloticus). Jurnal Sains Akuakultur Tropis 1(2) : 31-41.

Mangunwardoyo, W., R. Ismayasari, dan E. Riani. 2010. Uji Patogenisitas dan Virulensi Aeromonas hydrophila Stanier pada Ikan Nila (Oreochromis niloticus Lin.) melalui Postulat Koch. Jurnal Riset Akuakultur, 5 : 245-255.

Mastuti, R., H. Syawal dan I. Lukistyowati. 2018. Pengobatan Penyakit MAS (Motile Aeromonas Septicaemia) dengan Ekstrak Daun Mangrove (Rhizophora sp.) pada Ikan Jambal Siam (Pangasius hypophthalmus). Jurnal Online Mahasiswa. 5(1) : 1-10

Safratilofa. 2017. Histopatologi Hati dan Ginjal Ikan Patin (pangasionodon hypopthalmus) yang Diinjeksi Bakteri Aeromonas hydrophila. Jurnal Akuakultur Sungai dan Danau, 2(2), 83-88.

Samsundari, S. 2006. Pengujian Ekstrak Temulawak dan Kunyit Terhadap Resistensi Bakteri Aeromonas hydrophila yang Menyerang Ikan Mas (Cyprinus carpio). Jurnal Gamma, 2(1), 71-83.

Santika, A. 2013. Gambaran Parameter Hematologis pada Ikan Nila (Oreochromis niloticus) yang Diberi Vaksin DNA Streptococcus iniae dengan Dosis yang Berbeda. Journal of Aquaculture Management and Technology. 2(4):7-20.

Selvi, N.Z., M. Riauwaty, dan H. Syawal. 2016. Histopathology Kidney of Pangasisus hypopthalmus That Are Immersed In Curcumin and Were Infected by Aeromonas hydrophila. Jurnal Online Mahasiswa, 3(2), 1-11

Septiana, R. 2011. Identifikasi dan Uji Aktivitas Bakteri Fraksi Teraktif Daun Sirih Merah (Piper crocatum Ruiz \& Pav.). Skripsi. Fakultas Matematika dan Ilmu Pengetahuan Alam. Universitas Sebelas Maret. Surakarta. 70 hlm

Taukhid, L. Gardenia, dan S. Andriyanto. 2016. Efikasi Vaksin Kombinasi "Trivalen" (Aeromonas hydrophila, Streptococcus agalactiae, dan Mycobacterium fortuitum) untuk Pencegahan Penyakit Bakteri Potensial Abstrak pada Budidaya Ikan Air Tawar. Jurnal Riset Akuakultur, 11(4): 373-385. DOI: 10.15578/ jra.11.4.2016.373-385

Windarti, dan A.H. Simarmata. 2015. Buku Ajar Struktur Jaringan. Pekanbaru, Indonesia: Penerbit Unri Press.

Wahyuni, S., Windarti dan R.M. Putra. 2017. Comparative Study on Histological Structure of Gill and Kidney of Snakehead Fish (Channa striata, BLOCH 1793) from The Kulim and Sibam Rivers, Riau Province. Jurnal Online Mahasiswa. 4(2). 1-14.

Wikiandy, N. 2013. Dampak Pencemaran Limbah Industri Tekstil terhadap Kerusakan Struktur Organ Ikan yang Hidup di DAS (Daerah Aliaran Sungai) Citarum Bagian Hulu. Skripsi. Universitas Padjajaran. Bandung. $50 \mathrm{hlm}$.

Yolanda, F. 2019. Diferensiasi Leukosit Ikan Jambal Siam (Pangasius hypophthalmus) yang diberi Pakan mengendung Tepung Kunyit dan Diuji Tantang dengan Aeromonas hydrophila. Skripsi. Pekanbaru, Indonesia: Fakultas Perikanan dan Kelautan. Universitas Riau. 